since in the individual patient the degree of abnormality of oesophageal motility does not correlate closely with that of insulin-induced gastric secretion vagal impairment may predominantly affect different parts of the gut in different patients and may indeed be as highly selective as current surgical vagotomy. Vagal impairment complicating diabetics may, by the resulting reduction in gastric acid secretion, account for the low incidence of duodenal ulcer in this disease, and our findings indicate that this is a more likely mechanism than reduction of parietal cell mass as a consequence of gastric mucosal atrophy.

We thank the patients for their co-operation and Dr. M. V. Wells and Dr. S. P. Allison for referring them for study. We also thank the medical illustration department of Nottingham General Hospital.

Requests for reprints should be addressed to M.A.
2 Zschoch, H., Deutsche Zeitschrift fur Verdauungs-und Stoffwechselkrankheiten, 1965, 25, 97.

3 Dotevall, G., Acta Medica Scandinavica, 1961, 170, 59.
4 Segovia, D. A., Torre, E., and Domenge, L., Revista de Investigacion Clinica, 1960, 12 , 45.

5 Angervall, L., Dotevall, G., and Lehmann, K. E., Acta Medica Scandinavica, 1961, 169, 339

6 Wilkinson, J. F., British Medical fournal, 1963, 1, 676.

7 Kassander, P., Annals of Internal Medicine, 1958, 48, 797.

Whalen, G. E., Soergel, K. H., and Geenen, J. E., Gastroenterology, $1969,56,1021$.

9 Malins, J. M., and Mayne, N., Diabetes, 1969, 18, 858.

10 Barnes, A. D., and Cox, A. G., in After Vagotomy, ed. J. A. Williams and A. G. Cox, p. 221. London, Butterworth, 1969.

11 Baron, J. H., Scandinavian Fournal of Gastroenterology, 1970., Suppl. 6, 9. 12 Hollander, F., Gastroenterology, 1946, 7, 607.

13 Johnston, D., and Jepson, K., Lancet, 1967, 2,585

14 Venables, C. W., and Johnston, I. D., British fournal of Surgery, 1969, 57,757 .

15 Marks, I. N., Schuman, C. R., and Shay, H., Annals of Internal Medicine, $1959,51,227$.

16 de Mowbray, R. R., et al., Diabetologia, 1971, 7, 476

17 de Mowbray, R. R., et al., Diabetologia, 1971, 7, 476.

17 Dotevall, G., et al., Acta Medica Scandina

18 Burns, G. P., et al., Gut, 1969, 10, 820.

19 Langer, L., Acta Medica Scandinavica,

\title{
Localized Avascular Necrosis of Lesser Curve of Stomach Complicating Highly Selective Vagotomy
}

\author{
JAN F. HALVORSEN, PETER HEIMANN， JAN H. SOLHAUG， KNUT B. JACOBSEN
}

British Medical fournal, 1975, 2, 590-591

\section{Summary}

The fourth case of localized avascular necrosis of the lesser curve of the stomach after highly selective vagotomy is reported. The pathogenesis was probably related to the relative poverty of the submucosal blood supply along the lesser curve. This complication may be prevented by peritonealizing the lesser curve before closing the abdominal wall.

\section{Introduction}

Interest in highly selective vagotomy without a drainage procedure (H.S.V.) in the treatment of duodenal ulcer is increasing. The operation effectively reduces the acid output and early and late complications are less frequent than after other operations for duodenal ulcer. ${ }^{1-12}$ Among 350 patients who were followed for up to five years after H.S.V. in Leeds and Copenhagen there were no cases of proved recurrent duodenal ulceration and only two cases of gastric ulcer. ${ }^{11}$

Only three deaths after H.S.V. have been reported, two of them after operation for duodenal ulcer $^{13} 14$ and one after operation for gastric ulcer.11 We report here the third death after H.S.V. for duodenal ulcer, which bears a striking resemblance to those reported by Newcombe ${ }^{13}$ and Hall et al..$^{14}$

\footnotetext{
Department of Surgery, Haukeland Sykehus, University of Bergen, Bergen, Norway

J. F. HALVORSEN, M.D., Senior Registrar

P. HEIMANN, M.D., PH.D., Professor of Surgery

J. H. SOLHAUG, M.D., Senior Registrar

Department of Pathology, Gade Institute, Haukeland Sykehus,

University of Bergen, Bergen, Norway

K. B. JACOBSEN, M.D., Consultant Pathologist
}

\section{Case Report}

This 36-year-old man had a three-year history of recurrent duodenal ulceration. On 12 February 1974 H.S.V. was performed. The duodenal cap was scarred but there was no stenosis. No difficulty was encountered during the operation. Diathermy was not used, all vessels and nerves being ligated with 00 -silk. The raw surface of the lesser curve was not peritonealized. The patient was participating in a postoperative metabolic study, for which a subclavian catheter for intravenous alimentation and a nasogastric tube had been positioned.

Two days after operation the patient had pains in the epigastrium and left hypochondrium and became dyspnoeic. Chest $x$-ray examination showed a large bilateral hydrothorax. Thoracocentesis yielded $1400 \mathrm{ml}$ of milky fluid from the right pleura and $400 \mathrm{ml}$ from the left pleura. The fluid was a diluted solution of Intralipid, which the patient had received through the left subclavian vein. The subclavian catheter was removed.

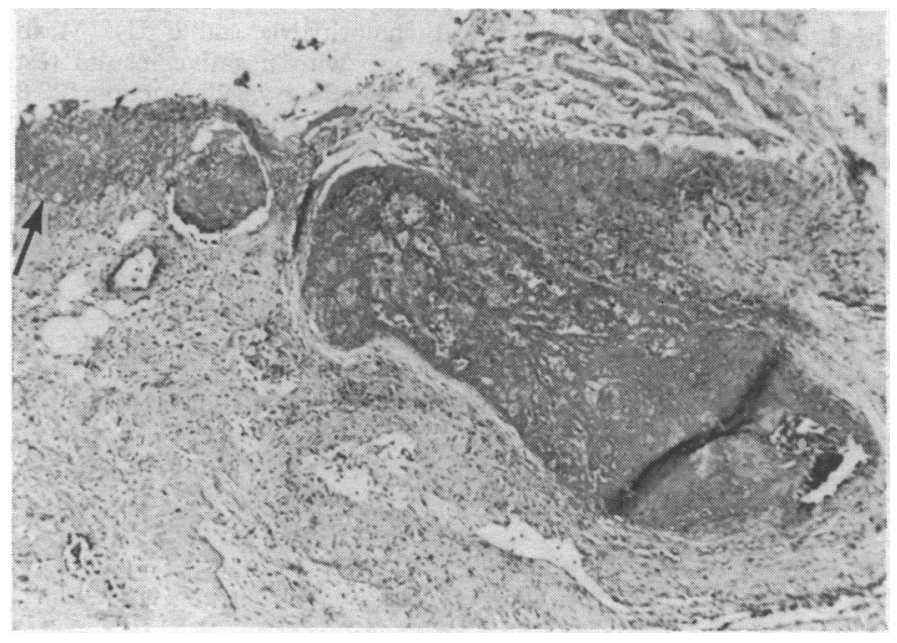

FIG. 1-Microscopic appearance of gastric perforation showing necrotic border (arrowed) and thrombosed vessel. $(H$. and $E$. $\times 36$.)

For the next three days the patient remained comparatively well. He passed flatus on the third day after operation, but the abdomen 
remained moderately distended. There was no tenderness or guarding. On 18 February he again became dyspnoeic, and chest $x$-ray examination showed a recurrent bilateral hydrothorax; $600 \mathrm{ml}$ of brownish fluid was aspirated from the left and $250 \mathrm{ml}$ from the right pleura. The patient became febrile and the abdomen rapidly distended. On 19 February cardiac arrest occurred, and resuscitation was unsuccessful.

Necropsy 26 hours after death showed diffuse peritonitis with fibrinous adhesions and $400 \mathrm{ml}$ of purulent fluid. A large subphrenic abscess was located under the right hemidiaphragm. A perforation, measuring $3 \times 2 \mathrm{~cm}$, was found on the lesser curve $3 \mathrm{~cm}$ below the cardia. Microscopy showed a necrotic border along the edge of the perforation with inflammatory cells in the tissue around it. Near the perforation's surface a thrombosed medium sized vessel could be followed through the submucosa (fig. 1). The vessels of the neck and the mediastinum were carefully dissected; in the left innominate vein an irregular patch, measuring $1 \times 1 \times 0.5 \mathrm{~cm}$ and consisting of a shaggy fibrinous material covering an area where the intima was lacking, was found on the intimal side. An inflammatory exudate with lymphocytes and some neutrophils was present in the vein wall (fig. 2).

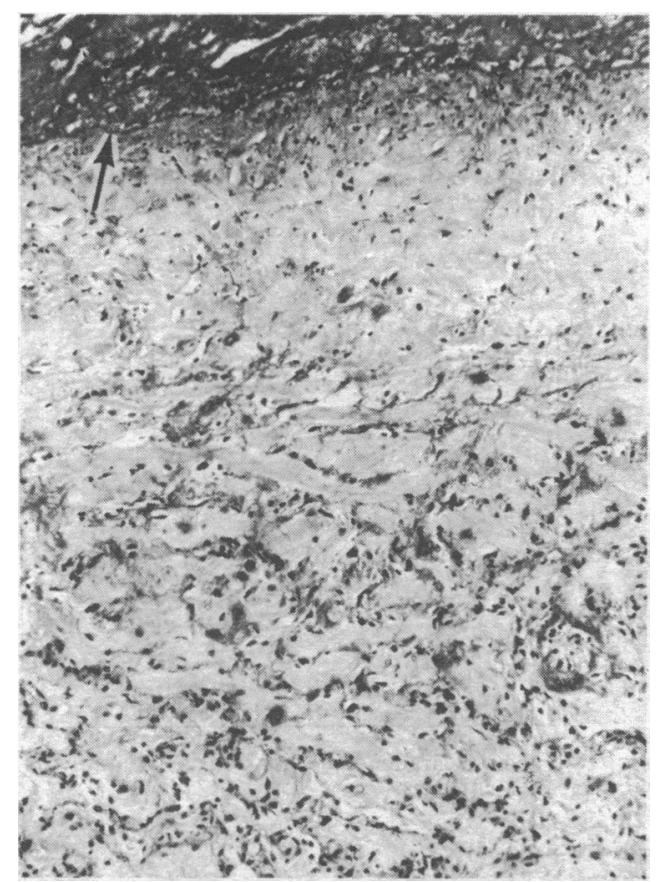

FIG. 2-Microscopic appearance of wall of innominate vein with fibrinous layer (arrowed) and inflammatory cells in vessel wall. $(\mathrm{H}$. and $\mathrm{E} . \times 88$.

\section{Discussion}

Perforation of the stomach with diffuse peritonitis caused the death of this patient. The perforation could not have been made inadvertently at operation, and the history indicates that it occurred two days after operation, when the peritonitis probably was localized. Because of the complication due to the subclavian catheter, with perforation of the left innominate vein and intrapleural infusion of Intralipid, the symptoms and signs were all ascribed to this complication, and diagnosis of the gastric perforation was fatally delayed.

Gastric perforation was probably caused by local ischaemia of the corresponding area of the lesser curve. The anterior and posterior walls of the stomach and the greater curve have a very rich anastomosing submucous vascular plexus, but the lesser curve has a poorer blood supply and different pattern. The tissue along the lesser curve and for $1-2 \mathrm{~cm}$ on either side is supplied by slender vessels arising from the right and left gastric arteries. They may be connected by anastomotic branches before piercing the muscle coats to reach the submucosa, which they traverse without the formation of a submucous plexus. ${ }^{15}$ Potential areas of ischaemia, therefore, are present along the lesser curve. Vagotomy immediately reduces gastric mucosal blood flow, probably by opening up submucosal arteriovenous shunts, ${ }^{16-18}$ and around the lesser curve, where the submucous vascular plexus is lacking, this mechanism may produce ischaemic necrosis. The edge of the perforation showed thrombosis of the vessels, but it is difficult to decide whether this was the cause or the effect of the perforation.

Our fatal case is the fourth of its kind to be reported, though Wyllie et al. ${ }^{19}$ reported an identical complication in a patient who had also had a pyloroplasty; the patient survived after a reoperation to suture the perforation. A recent review of H.S.V. showed that in over 1000 H.S.V.s for duodenal ulcer there had not been one operative death. ${ }^{11}$ The chances of avascular necrosis of the lesser curve occurring after H.S.V., therefore, seem very small. To prevent the serious consequences of such necrosis, however, the lesser curve should be peritonealized before closing the abdominal wall. Hall et al. ${ }^{14}$ use the greater omentum to cover the raw surface of the lesser curve but we approximate the peritoneum on the anterior and posterior gastric walls with interrupted polyglycolic acid sutures. This also prevents possible reinnervation of the lesser curve. ${ }^{8} 20$

Avascular necrosis of the lesser curve should be suspected in patients who develop symptoms and signs of paralytic ileus without obvious cause ${ }^{13} 14$ or frank peritonitis. ${ }^{19}$

\section{References}

1 Amdrup, E., and Jensen, H.-E., Gastroenterology, 1970, 59, 522.

Johnston, D., and Wilkinson, A. R., British fournal of Surgery, 1970, 57, 289.

${ }^{3}$ Hedenstedt, S., and Moberg, S., Acta Chirurgica Scandinavica, 1971, 137, 547.

${ }^{4}$ Clarke, R. J., et al., Gut, 1972, 13, 842.

5 Hedenstedt, S., Lundquist, G., and Moberg, S., Acta Chirurgica Scandinavica, 1972, 138, 591.

6 Imperati, L., Natale, C., and Marinaccio, F., British fournal of Surgery, $1972,59,602$

Wastell, C., et al., British Medical fournal, 1972, 1, 28.

8 Grassi, G., et al., Surgery, Gynecology and Obstetrics, 1973, 136, 726.

9 Johnston, D., et al., British Fournal of Surgery, 1973, 60, 790.

10 Amdrup, E., et al., Annals of Surgery, 1974, 180, 279.

11 Johnston, D., Gut, 1974, 15, 748.

Kragelund, E., Fischer, J. E., and Nielsen, A., Annals of Surgery, 1974, $179,174$.

13 Newcombe, J. F., British Medical fournal, 1973, 1, 610.

14 Hall, R., Summers, G. A. C., and Green, M. A., British Medical fournal, $1974,3,806$.

15 Barlow, T. E., Bentley, F. H., and Walder, D. N., Surgery, Gynecology and Obstetrics, 195i, 93, 657.

16 Nylander, G., and Olerud, S., Surgery, Gynecology and Obstetrics, 1961,

17 Olsen, W. R., Foley, W. J., and Simon, M. A., American fournal of Surgery, 1970, 119, 183 .

Surgery, 1970, 119, 183.
Mackie, D. B., and Turner, M. D., Archives of Surgery, 1971, $102,626$.

19 Wyllie, J. H., British Medical fournal, 1974, 2, 561.

20 Grassi, G., Surgery, Gynecology and Obstetrics, 1975, 140, 259. 